\title{
Phytochemical screening and evaluation of phytotoxic activity of Solanum lycocarpum (Solanaceae) ripe fruit
}

\author{
Iara Cotta Mendesa, Paula Avelar Amadob, Melissa Graziele Morais ${ }^{b}$, Luciana Alves Rodrigues \\ dos Santos Limab,c* \\ a Universidade de São João Del Rei, Divinópolis, 35501-296, Minas Gerais, Brazil. \\ b Programa de Pós-Graduação em Biotecnologia, Universidade de São João Del Rei, Divinópolis, 35501-296, Minas Gerais, Brazil. \\ c Programa de Pós-Graduação em Ciências Farmacêuticas, Universidade de São João Del Rei, Divinópolis, 35501-296, Minas Gerais, \\ Brazil.*luarsantos@ufsj.edu.br
}

Received: August 26, 2019 / Accepted: October 22, 2019 / Published online: January 20, 2020

\begin{abstract}
The species Solanum lycocarpum A. St. Hil. (wolf fruit), belonging to the Solanaceae family, is used in folk medicine for the treatment of obesity, diabetes, and cholesterol reduction. The aim of this study was to perform phytochemical screening of the ethanol extract from the ripe fruit of S. lycocarpum to verify the presence of the main groups of secondary metabolites and to evaluate the phytotoxic effect on Lactuca sativa (lettuce) and Allium cepa (onion) seeds exposed to different concentrations of extract $(125,250$ and $500 \mu \mathrm{g}$ per plate). The fruits of $S$. lycocarpum were collected, crushed and percolated with anhydrous ethanol and the solvent was dried in a rotatory evaporator to obtain the ethanol extract. The ethanol extract was able to completely inhibit the growth of hypocotyl and radicle of $L$. sativa (lettuce) seeds in all concentrations tested. In A. cepa (onion) seeds, a concentration of $500 \mu \mathrm{g}$ per plate was able to inhibit the growth of the hypocotyl and radicle by $100 \%$. The metabolites detected in the extract were alkaloids, coumarins, flavonoids, and condensed tannins. The phytotoxic activity can be correlated to the presence of these compounds.
\end{abstract}

Keywords: Allium cepa, Lactuca sativa, secondary metabolites, wolf fruit, ethanol extract.

\section{Triagem fitoquímica e avaliação da atividade fitotóxica do fruto maduro de Solanum lycocarpum (Solanaceae)}

\begin{abstract}
Resumo
A espécie Solanum lycocarpum A. St. Hil. (lobeira ou fruto do lobo), pertencente à família Solanaceae, é utilizada na medicina popular para o tratamento da obesidade, do diabetes e na redução do colesterol. O objetivo deste estudo foi realizar a triagem fitoquímica do extrato etanólico do fruto maduro de $S$. lycocarpum para verificar a presença dos principais grupos de metabólitos secundários e avaliar o efeito fitotóxico sobre sementes de Lactuca sativa (alface) e de Allium cepa (cebola) expostas a diferentes concentrações do extrato (125, 250 and $500 \mu \mathrm{g}$ por placa). Os frutos de $S$. lycocarpum foram coletados, triturados e extraídos por percolação com etanol anidro e, o solvente foi secado em evaporador rotatório, obtendo-se o extrato etanólico. O extrato etanólico foi capaz de inibir completamente o crescimento do hipocótilo e da radícula de sementes de $L$. sativa (alface), em todas as concentrações testadas. Nas sementes de A. cepa (cebola), a concentração de $500 \mu \mathrm{g}$ por placa foi capaz de inibir em $100 \%$ o crescimento do hipocótilo e da radícula. Os metabólitos detectados no extrato foram alcaloides, cumarinas, flavonoides e taninos condensados. A atividade fitotóxica pode ser correlacionada à presença desses compostos.
\end{abstract}

Palavras-chave: Allium cepa, Lactuca sativa, metabólito secundário, lobeira, extrato etanólico.

\section{Introduction}

The growth of the world's population, combined with a greater demand for food production, has increased the use of herbicides for weed control. Synthetic herbicides cause damage to human health and the environment, such as triggering changes in resistance to invasive species, contamination of aquatic systems, and toxicity to humans. Researchers have been increasingly interested in finding natural compounds that can be used as bioherbicides to replace synthetic herbicides, and that are less environmentally harmful, water-soluble and less toxic (Matsumoto, Ribeiro, Takao, \& Lima, 2010).

Secondary metabolites synthesized by plants and belonging to various classes (terpenes, alkaloids, phenolic compounds, steroids, long-chain fatty acids, unsaturated lactones) may act as allelochemicals and are regulated or altered by various environmental factors such as climate, and soil. Allelochemicals interfere in different ways in plant 
communities to generate phytotoxic effects, such as decreasing plant growth due to inhibition of mitosis (Sanchez-Moreiras, De la Pena, \& Reigosa, 2008), affecting the conservation, dormancy, germination, vegetative vigor, growth of seedlings and adult plants, and influencing species competition (Yamagushi, Gusman, \& Vestena, 2011). Thus, the search for herbicides with different mechanisms of action from those already existing is of great importance, and plants with allelopathic effects could be a natural herbicide source (Alvarenga et al., 2009).

The species S. lycocarpum is found in the Brazilian Cerrado and is popularly known as cerrado eggplant or wolf fruit (Munari et al., 2012). This species is widely used in folk medicine as a sedative, in the treatment of epilepsy, diabetes, obesity, reduction of cholesterol levels, and in the preparation of influenza syrups (Dall'Agno \& Von Poser, 2000). Previous studies have shown that fruits of $S$. lycocarpum exhibit allelopathic, anti-inflammatory, antimicrobial, antioxidant, antitumoral, cytotoxic, genotoxic and larvicidal activities (Morais, Silva, Oliveira, Ferreira, \& Lima, 2013; Pereira, Silva, Ribeiro Neto, Alves, \& Lima, 2014; Morais et al., 2015; Silva, Ribeiro Neto, Alves, \& Lima, 2015; Chiavegatto, Chaves, Silva, Lima, \& Techio, 2017; Morais et al., 2017; Bahia et al., 2018; Morais et al., 2018; Silva et al., 2018; Silva, Fonseca, Coimbra, Duarte-Almeida, \& Lima, 2019).

Due the biological effects and low cytotoxicity of ripe fruits from S. lycocarpum, the contribution of this work is important to verify the phytotoxic effect of ethanol extract on lettuce and onion seeds.

\section{Material and Methods}

\section{Plant material and extraction}

S. lycocarpum ripe fruits were collected in the Cerrado region São Sebastião do Oeste, Midwest Minas Gerais State, Brazil (20 $144^{\prime} 38.96^{\prime \prime} \mathrm{S}$ and $45^{\circ} 2^{\prime} 14.38^{\prime \prime} \mathrm{W}$ ) (SISBIO n. 30006). Fertile samples were collected, and vouchers were identified by Dr. Alexandre Salino, and deposited in the Institute of Biological Sciences Herbarium (BHCB 159397) at the Federal University of Minas Gerais (UFMG). This research has access permission to the components of plant genetic heritage (n. 010655/2011-5/CNPq/CGEN/MMA) and it is registered in the SisGen Platform (Register AEF6C95), according to Brazilian Biodiversity Law (13.123/2015).

Extraction of the dried and powdered fruits $(2086.13 \mathrm{~g})$ by percolation (ethanol, $7 \mathrm{~L}$ ) produced $48.02 \mathrm{~g}$ of ethanol extract (EE).

\section{Phytochemical analysis}

Phytochemical screening of the extract was performed to evaluate the presence of the main classes of secondary metabolites: flavonoids, coumarins, alkaloids (Silva, Miranda, \& Conceição, 2010), saponins, tannins, steroids and triterpenoids (Matos, 2009).

\section{Phytotoxic activity test by bioautography}

Phytotoxicity was evaluated using seeds of Lactuca sativa L. var. Winter Curly (lettuce) (Feltrin $®$, Lot 46631196, Brazil) and Allium cepa cv. Baia Periforme (onion) (Feltrin ${ }^{\circledR}$, Lot 450865, Brazil) according to the methodology described by Tonelli et al. (2014). The ethanol extract applied in chromatography plates of silica gel matrix $(5.5 \times 5.5 \mathrm{~cm})$ with fluorescent indicator staining (Sigma-Aldrich) was eluted into the chromatography chamber using ethyl acetate/acetic acid/water (100:22:26) and visualized under UV light at $254 \mathrm{~nm}$. The chromatographic profile of the ethanol extract by TLC plate exhibited four spots with different retention factors (Rfs). Rf 0.0 corresponded to the beginning of the chromatographic run, and Rf 0.9 (last spot in the plate). The intermediate profile was found between Rfs 0.0 and 0.9 , and was a portion apparently free of substances. At the end of the chromatographic run was Rf 1.0.

$$
\mathrm{Rf}=\frac{\text { distance spot moved }}{\text { distance solvent moved }} \quad \text { (Eq. 1) }
$$

The chromatography plates with ethanol extract then were placed into Petri dishes $(10.0 \varnothing)$. One filter paper $(9 \mathrm{~cm}$ in diameter) was placed over the extract-containing chromatography plates, 25 seeds were placed on top, and 10 $\mathrm{mL}$ of MES buffer ( $\mathrm{pH}$ 6.0-6.2) was then added. In the control group was added the same amount of buffer to a Petri dish, containing a blank chromatography plate and the same amount of seeds. The test was performed in triplicate for different concentrations of extract $(125,250$ and $500 \mu \mathrm{g}$ per plate) and control group.

After a week of incubation in the dark, the Petri dishes were frozen at $-10{ }^{\circ} \mathrm{C}$ for $24 \mathrm{~h}$ to stop plant growth. The size of hypocotyls and radicles of germinated A. cepa and $L$. sativa seeds were measured (Tonelli et al., 2014). The effects on growth of hypocotyls and radicles were calculated according by Pinto, Silva, Siqueira, Santos, \& Lima (2013), which zero represents the control, positive values represent stimulation of growth, and negative values represent inhibition of growth.

\section{Chemicals}

For this study, 2-( $N$-morpholino) ethanesulfonic acid (MES) purchased from Sigma-Aldrich ${ }^{\circledR}$ (USA) was used. Sulfuric acid, ethanol, ferric chloride, sodium hydroxide, ethyl acetate, toluene and acetic anhydride purchased from Cromato Produtos Químicos® (Brazil). The reagents basic bismuth nitrate, potassium iodide and acetic acid were obtained from Vetec ${ }^{\circledR}$ (Brazil).

\section{Statistical analysis}

A Student's t-test was used to evaluate the statistical difference between the control group and the group exposed to ethanol extract of S. lycocarpum. The Tukey test was used to evaluate the statistical difference between growth of hypocotyl and radicle. The analyses were performed using GraphPad Prism 5.0 software (San Diego, CA, USA). Values were considered statistically significant at $p<0.05$.

\section{Results and Discussion}

Phytochemical tests revealed the presence of alkaloids, coumarins, flavonoids, and condensed tannins in the ethanol extract, and absence of anthraquinones, steroids, triterpenes, 
and saponins. A previous study with ripe fruits of this species (Morais et al., 2013) detected the presence of similar compounds in the ethanol extract as in our research; the exception was the absence of tannins. Phytochemical tests also showed the presence of coumarins, flavonoids, and tannins in the methanol extract from unripe fruits (Pereira et al., 2014). Many biological activities are correlated to the bioactive secondary metabolites present in plants (Oliveira, Gualtieri, Domíngues, Molinillo, \& Montoya, 2012).
The ethanol extract exhibited strong phytotoxic effects on the hypocotyl and radicle of L. sativa, inhibiting $100 \%$ of growth in all Rfs, at all three concentrations tested. The hypocotyl and radicle growth of A. cepa seeds was also strongly inhibited (Table 1). The best inhibitory effects were observed at $500 \mu \mathrm{g}$ per plate in all Rfs, and $250 \mu \mathrm{g}$ per plate in the application ( $\mathrm{Rf} 0.0$ ), with $100 \%$ inhibition of hypocotyl and radicle growth.

Table 1. Phytotoxic effects of the ethanol extract from S. lycocarpum fruits on the hypocotyl and radicle growth of A. cepa.

\begin{tabular}{ccccccc}
\hline \multirow{2}{*}{ Samples } & \multicolumn{5}{c}{ Growth (\% Control) } \\
\cline { 2 - 6 } & \multicolumn{5}{c}{ Hypocotyl } & \multicolumn{3}{c}{ Radicle } \\
\cline { 2 - 6 } & 125 & 250 & 500 & 125 & 250 & 500 \\
\hline RF 0.9 & $91.38 \pm 0.21^{\mathrm{a}}$ & $90.62 \pm 0.23^{\mathrm{a}}$ & $100.00 \pm 0.00^{\mathrm{b}}$ & $79.43 \pm 0.19^{\mathrm{c}}$ & $80.09 \pm 0.18^{\mathrm{c}}$ & $100.00 \pm 0.00^{\mathrm{b}}$ \\
Intermediate & $81.35 \pm 0.46^{\mathrm{c}}$ & $85.40 \pm 0.36^{\mathrm{d}}$ & $100.00 \pm 0.00^{\mathrm{b}}$ & $64.44 \pm 0.34^{\mathrm{e}}$ & $80.89 \pm 0.18^{\mathrm{c}}$ & $100.00 \pm 0.00^{\mathrm{b}}$ \\
Application & $79.14 \pm 0.51^{\mathrm{c}}$ & $100.00 \pm 0.00^{\mathrm{b}}$ & $100.00 \pm 0.00^{\mathrm{b}}$ & $43.13 \pm 0.54^{\mathrm{f}}$ & $100.00 \pm 0.00^{\mathrm{b}}$ & $100.00 \pm 0.00^{\mathrm{b}}$ \\
\hline
\end{tabular}

Different concentrations of extract $(125,250$ and $500 \mu \mathrm{g}$ per plate). The results are means \pm SD $(n=3)$. Means followed by the same letter do not differ according to the Tukey test $(p<0.05)$.

These results suggest that the ethanol extract presented great phytotoxic potential. In the phytotoxic assay, the ethanol extract (in all Rfs) was statistically significant when compared to the control $(p<0.05)$.

The growth inhibition of hypocotyl and radicle in L. sativa and $A$. cepa seeds when exposed to ethanol extract can be related to the secondary metabolites detected in phytochemical screening. Flavonoids, alkaloids, and coumarins can interfere with development by affecting the plant growth process (Soares, Scalon, Pereira, \& Vieira, 2002). Coumarins are indicated as potent inhibitors of plant growth and seed germination by possessing the ability to block mitosis (Rice, 1984; Abenavoli et al., 2006; Willis, 2007).

There are some reports about the allelopathic activity of $S$. lycocarpum. Morais et al. (2013) showed the allelopathic potential of the ethanol extract and fractions (125, 250 and 500 $\mu \mathrm{g} / \mathrm{mL}$ ) from ripe fruits on L. sativa and A. cepa seeds, with inhibition in the range of 5-86\% and 7-96\%, respectively. Silva et al. (2019) evaluated the allelopathic effect of unripe fruit $(50,100$ and $200 \mu \mathrm{g} / \mathrm{mL})$ and the best results were for the hexane extract on hypocotyl and radicle of A. cepa seeds, with inhibitions of $52.7 \%$ and $41.3 \%$, respectively, at a concentration of $200 \mu \mathrm{g} / \mathrm{mL}$.

\section{Conclusion}

The ethanol extract from ripe fruits of $S$. lycocarpum showed potential phytotoxicity to the seeds of $A$. cepa and $L$. sativa. To the best of our knowledge, reports about the phytotoxic potential of the S. lycocarpum have not found.

\section{References}

Abenavoli, M., Cacco, G., Sorgoná, A., Marabottini, R., Paolacci, A., Ciaffi, M., \& Badiami, M. (2006). The inhibitory effects of coumarin on the germination of durum wheat (Triticum turgidum ssp. durum, cv. Simeto) seeds. Journal of Chemical Ecology, 32(2), 489-506. doi: 10.1007/s10886-005-9011-x

Alvarenga, E. S., Barbosa, L. C. A., Saliba, W. A., Arantes, F. F. P., Demuner, A. J., \& Silva, A. A. (2009). Synthesis and evaluation of the phytotoxic activity of $\alpha$-Santonin derivatives. Química Nova, 32(2), 401-406. doi: $10.1590 / S 0100-40422009000200025$
Bahia, J. P., Silva, V. C. B., Morais, M. G., Costa, G. A. F., Ferreira, J. M. S., Duarte-Almeida, J. M., \& Lima, L. A. R. S. (2018). Total phenolic and total flavonoid content, antioxidant, antibacterial, and allelopathic activities of the methanol extract and fractions from Solanum lycocarpum A. St. Hil. (Solanaceae). In: I. S. Rocha (Orgs.), Solanaceae: Cultivation, Nutrition and Health (Cap. 3, pp. 63-78). New York: Nova Science Publishers.

Chiavegatto, R. B., Chaves, A. L. A., Silva, I. C. A., Lima, L. A. R. S., \& Techio, V. H. (2017). Cytotoxic and genotoxic effects of Solanum lycocarpum St. -Hil (Solanaceae) on the cell cycle of Lactuca sativa and Allium cepa. Acta Scientiarum Biological Sciences, 39(2), 201210. doi: $10.4025 /$ actascibiolsci.v39i2.34082

Dall'Agnol, R., \& Von Poser, G. L. (2000). The use of complex polysaccharides in the management of metabolic diseases: the case of Solanum lycocarpum fruits. Journal of Ethnopharmacology, 71(1-2), 337-341. doi: 10.1016/S0378-8741(00)00165-3

Matos, F. J. A. (2009). Introdução à fitoquímica experimental (2a ed.). Ceará: Edições UFC.

Matsumoto, R. S., Ribeiro, J. P. N., Takao, L. K., \& Lima, M. I. S. (2010). Allelopathic potential of leaf extract of Annona glabra L. (Annonaceae). Acta Botanica Brasilica, 24(3), 631-635. doi: 10.1590/S0102-33062010000300005

Morais, M. G., Silva, V. C. B., Oliveira, G. T., Ferreira, J. M. S., \& Lima, L. A. R. S. (2013). Allelopathic potential of the ripe fruits of Solanum lycocarpum A. St. Hil. (Solanaceae). Biochemistry and Biotechnoogy Reports, 2(2), 37-41. doi: 10.5433/2316-5200.2013v2n2p37

Morais, M. G., Costa, G. A. F., Aleixo, A. A., Oliveira, G. T., Alves, L. F., Duarte-Almeida, J. M., Ferreira, J. M. S., \& Lima, L. A. R. S. (2015). Antioxidant, antibacterial and cytotoxic potential of the ripe fruits of Solanum lycocarpum A. St. Hil. (Solanaceae). Natural Product Research, 29(5), 480-483. doi: 10.1080/14786419.2014.951930

Morais, M. G., Costa, G. A. F., Silva, I. C. A., Silva, A. G., Ribeiro, R. I. M. A., Ferreira, J. M. S., Duarte-Almeida, J. M., Pinto, F. C. H., \& Lima, L. A. R. S. (2017). Inhibiting the development of solid Ehrlich tumor by extract of the ripe fruits of Solanum lycocarpum. In: H. R. Collins (Orgs.), Caffeic Acid, Potential Uses and Health Benefits (Cap. 3, pp. 83-96). New York: Nova Science Publishers.

Morais, M. G., Saldanha, A. A., Mendes, I. C., Rodrigues, J. P. C., Souza, A. C. S., \& Lima, L. A. R. S. (2018). Avaliação da atividade antiinflamatória via oral da fração diclorometânica dos frutos de Solanum lycocarpum. In: B. J. M. Sousa, B. C. Alves, J. M. Duarte-Almeida (Orgs.), Plantas Medicinais: Os Avanços das Pesquisas no Século XXI (Cap. 9, pp. 117-129). Divinópolis: Gulliver Editora Ltda.

Munari, C. C., Oliveira, P. F., Lima, I. M. S., Martins, S. P. L., Costa, J. C., Bastos, J. K., \& Tavares, D. C. (2012). Evaluation of cytotoxic, genotoxic and antigenotoxic potential of Solanum lycocarpum fruits glicoalkaloid extract in V79 cells. Food and Chemistry Toxicology, 50(10), 3696-3701. doi: 10.1016/j.fct.2012.07.028 
Oliveira, S. C. C., Gualtieri, S. C. J., Domíngues, F. A. M., Molinillo, J. M. G., \& Montoya, R. V. (2012). Phytochemistry of Solanum lycocarpum A. St. -Hil. (Solanaceae) leaves and their application in allelopathy. Acta Botanica Brasilica, 26(3), 607-618. doi: 10.1590/S010233062012000300010

Pereira, T. M., Silva, V. C. B., Ribeiro Neto, J. A., Alves, S. N., \& Lima, L. A. R. S. (2014). Larvicidal activity of the methanol extract and fractions of the green fruits of Solanum lycocarpum (Solanaceae) against the vector Culex quinquefasciatus (Diptera: Culicidae). Revista da Sociedade Brasileira de Medicina Tropical, 47(5), 646-648. doi: 10.1590/00378682-0010-2014

Pinto, M. E. A., Silva, N. L., Siqueira, E. P., Santos, F. J. L., \& Lima, L. A. R. S. (2013) Allelopathic effect of fatty acid methyl esters from corn and sunflower oils. Biochemistry and Biotechnology Reports, 2(1), 44-48. doi: 10.5433/2316-5200.2013v2n1p44

Rice, E. L. (1984). Allelopathy. Orlando: Academic Press.

Sanchez-Moreiras, A. M., de la Peña, T. C., \& Reigosa, M. J. (2018). The natural compound benzoxazolin-2(3H)-one selectively retards cell cycle in lettuce root meristems. Phytochemistry, 69(11), 2172-2179. doi: 10.1016/j.phytochem.2008.05.014

Silva, N. L. A., Miranda, F. A. A., \& Conceição, G. M. (2010). Triagem Fitoquímica de Plantas de Cerrado, da Área de Proteção Ambiental Municipal do Inhamum, Caxias, Maranhão. Scientia Plena, 6(2), 1-17. Recovered http://https://www.scientiaplena.org.br/sp/article/view/22

Silva, V. C. B., Ribeiro Neto, J. A., Alves, S. N., \& Lima, L. A. R. S. (2015). Larvicidal activity of the oils, fatty acids, and methyl esters from ripe and unripe fruits of Solanum lycocarpum (Solanaceae) against the vector Culex quinquefasciatus (Diptera: Culicidae). Revista da Sociedade Brasileira de Medicina Tropical, 48(5), 610-613. doi: 10.1590/00378682-0049-2015

Silva, V. C. B., Amado, P. A., Siqueira, E. P., Alves, S. N., Duarte-Almeida, J. M., \& Lima, L. A. R. S. (2018). Antioxidant and allelopathic potential of oils, fatty acids, and methyl esters from fruits of Solanum lycocarpum A. St. Hil. (Solanaceae). In: I. S. Rocha (Orgs.), Solanaceae: Cultivation, Nutrition and Health (Cap. 4, pp. 79-94). New York: Nova Science Publishers.

Silva, I. C. A., Fonseca, J. C., Coimbra, M. C., Duarte-Almeida, J. M., \& Lima, L. A. R. S. (2019). Total phenol and total flavonoid content, antioxidant and allelopathic activities of extracts of the unripe fruits of Solanum lycocarpum. Periódico Tchê Química, 16(31), 390-397. Recovered from http://www.deboni.he.com.br/Periodico31.pdf

Soares, G. L. G., Scalon, V. R., Pereira, T. O., \& Vieira, D. A. (2002). Potencial alelopático do extrato aquoso de folhas de algumas leguminosas arbóreas brasileiras. Floresta e Ambiente, 9, 119-126. Recovered from http://https://www.floram.org/article/588e21ffe710ab87018b45e3

Tonelli, F. M. P., Siqueira, J. M., Maia, G. A. S., Soares, L. F., Silva, D. B., Carollo, C. A., \& Sartori, A. L. B. (2014). Bioautography as a search tool to identify the allelopathic compounds in Virola sebifera. Allelopathy Journal, 33(2), 277-288. Recovered from https://eurekamag.com/research/066/284/066284201.php

Willis, R. J. (2007). The History of Allelopathy. Netherlands: Springer.

Yamagushi, M. Q., Gusman, G. S., \& Vestena, S. (2011). Allelopathic effect of aqueous extracts of Eucalyptus globules Labill. and of Casearia sylvestris Sw. on crops. Semina: Ciências Agrárias, 32(4), 1361-1374. doi: 10.5433/1679-0359.2011

\section{License: Creative Commons CC BY 4.0}

This article was published with open access for distribution under the terms of the Creative Commons Attribution License, which allows unrestricted use, distribution, and reproduction in any medium, provided the original work is properly cited. 